\title{
An Enzymic Analysis of NADPH Production and Consumption in Candida utilis
}

\author{
By PETER M. BRUINENBERG, JOHANNES P. VAN DIJKEN AND \\ W. ALEXANDER SCHEFFERS* \\ Laboratory of Microbiology, Delft University of Technology, Julianalaan 67A, 2628 BC Delft, \\ The Netherlands
}

(Received 5 August 1982)

Candida utilis CBS 621 was grown in chemostat cultures at $D=0 \cdot 1 \mathrm{~h}^{-1}$ on glucose, xylose, gluconate, acetate, or ethanol as the growth-limiting substrate with ammonia or nitrate as the nitrogen source and analysed for NADPH-producing and NADPH-consuming enzyme activities.

Nitrate and nitrite reductases were strictly NADPH-dependent. For all carbon sources, growth with nitrate resulted in elevated levels of HMP pathway enzymes. NADP+-linked isocitrate dehydrogenase did not vary significantly with the NADPH requirement for biosynthesis. Growth on ethanol strongly enhanced activity of NADP+-linked aldehyde dehydrogenase. Neither NADP+-linked malic enzyme nor transhydrogenase activities were detectable under any of the growth conditions. The absence of transhydrogenase was confirmed by the enzyme profiles of cells grown on mixtures of glucose and formate.

It is concluded that the HMP pathway and possibly NADP+-linked isocitrate dehydrogenase are the major sources of NADPH in Candida utilis.

\section{INTRODUCTION}

In the preceding paper (Bruinenberg et al., 1983) a theoretical analysis has been made of the NADPH requirement for yeast biomass formation. It was shown that this NADPH demand is strongly dependent on the available sources of carbon and nitrogen, and it was inferred that the carbon flow over NADPH-producing pathways should vary accordingly.

So far, little is known about the enzymology of $\mathrm{NADP}^{+}$reduction in yeasts. Radiorespirometric studies have indicated that during growth on glucose the hexose monophosphate (HMP) pathway is the major source of NADPH (Gancedo \& Lagunas, 1973). Indeed, it was found that the activity of glucose-6-phosphate dehydrogenase in Candida utilis and Aspergillus niger increased twofold when nitrate instead of ammonia was used as the nitrogen source (Osmond \& ap Rees, 1969; Hankinson \& Cove, 1974). On the other hand, no apparent correlation was observed between the activity of enzymes of NADPH-producing pathways and the NADPH demand in Candida tropicalis and Candida lipolytica (Hirai et al., 1976). A major impediment in the interpretation of such enzymological data has been the use of batch cultures. The rate of NADPH production is dependent on the growth rate and since batch cultures show large variations in growth rate depending on the carbon and nitrogen source, a comparative study of enzyme activities under various growth conditions is unsatisfactory.

In this paper an enzyme survey will be presented of NADPH-consuming and NADPHproducing pathways in Candida utilis, grown in chemostat cultures with various carbon and nitrogen sources at the same dilution rate. The data obtained will be compared with the theoretical predictions of required activities of these pathways under the growth conditions used, in order to answer the following questions.

(1) What are the main NADPH-producing pathways in Candida utilis? 
(2) Do the activities of enzymes operating in these routes vary in relation to the NADPH demand for biosynthesis?

(3) Is the HMP pathway also involved in generation of NADPH during growth of Candida utilis on non-sugar carbon sources?

\section{METHODS}

Micro-organism and growth conditions. Candida utilis CBS 621 was maintained on malt extract agar slopes. The organism was grown in chemostat cultures in a laboratory fermenter with a working volume of 1 litre, under carbon and energy limitation on a mineral medium at a dilution rate of $0 \cdot 1 \mathrm{~h}^{-1}$ at $30^{\circ} \mathrm{C}, \mathrm{pH} 5 \cdot 0$, and a dissolved oxygen concentration corresponding to $50 \%$ air saturation. The $\mathrm{pH}$ was controlled by automatic addition of $1 \mathrm{M}-$ $\mathrm{NaOH}$ or $0.5 \mathrm{M}-\mathrm{H}_{2} \mathrm{SO}_{4}$; the dissolved oxygen tension was recorded with a sterilizable Clark-type oxygen electrode. The mineral medium contained per litre: $\left(\mathrm{NH}_{4}\right)_{2} \mathrm{SO}_{4}, 5 \mathrm{~g}$, or $\mathrm{KNO}_{3}, 7 \cdot 7 \mathrm{~g}$, or methylammonium chloride, $2 \cdot 5 \mathrm{~g}$, or urea, $1.3 \mathrm{~g} ; \mathrm{KH}_{2} \mathrm{PO}_{4}, 3 \mathrm{~g} ; \mathrm{MgSO}_{4} .7 \mathrm{H}_{2} \mathrm{O}, 0.5 \mathrm{~g}$; EDTA, $15 \mathrm{mg} ; \mathrm{ZnSO}_{4} .7 \mathrm{H}_{2} \mathrm{O}, 4.5 \mathrm{mg} ; \mathrm{CoCl}_{2} .6 \mathrm{H}_{2} \mathrm{O}, 0.3 \mathrm{mg}$; $\mathrm{MnCl}_{2} .4 \mathrm{H}_{2} \mathrm{O}, 1 \mathrm{mg} ; \mathrm{CuSO}_{4} .5 \mathrm{H}_{2} \mathrm{O}, 0.3 \mathrm{mg} ; \mathrm{CaCl}_{2} .2 \mathrm{H}_{2} \mathrm{O}, 4.5 \mathrm{mg} ; \mathrm{FeSO}_{4} \cdot 7 \mathrm{H}_{2} \mathrm{O}, 3 \mathrm{mg} ; \mathrm{NaMoO}_{4} \cdot 2 \mathrm{H}_{2} \mathrm{O}$, $0.04 \mathrm{mg} ; \mathrm{H}_{3} \mathrm{BO}_{3}, 1 \mathrm{mg} ; \mathrm{KI}, 0.1 \mathrm{mg}$; and $0.025 \mathrm{ml}$ silicone antifoam $(\mathrm{BDH})$. After heat sterilization at $120^{\circ} \mathrm{C}$ and cooling, filter sterilized vitamins were added: biotin, $0.05 \mathrm{mg}$; calcium pantothenate, $1 \mathrm{mg}$; nicotinic acid, $1 \mathrm{mg}$; inositol, $25 \mathrm{mg}$; thiamin. $\mathrm{HCl}, 1 \mathrm{mg}$; pyridoxine. $\mathrm{HCl}, 1 \mathrm{mg}$; para-aminobenzoic acid, $0.2 \mathrm{mg}$. Carbon sources were heat-sterilized separately at $110^{\circ} \mathrm{C}$, except for ethanol which was filter-sterilized, and were added to the medium to give the following concentrations $\left(\mathrm{g}^{-1}\right)$ : glucose, 5 ; xylose, 5 ; sodium gluconate, 5 ; sodium acetate, 10 ; sodium formate, 5 ; ethanol, $3 \cdot 5$.

Preparation of cell-free extracts. Cells from $50 \mathrm{ml}$ samples of steady-state cultures were harvested by low-speed centrifugation, washed once with $10 \mathrm{~mm}$-potassium phosphate buffer of $\mathrm{pH} 7 \cdot 5$, containing 2 mM-EDTA, and resuspended in $100 \mathrm{~mm}$-potassium phosphate buffer $\mathrm{pH} 7.5$ containing $2 \mathrm{~mm}-\mathrm{MgCl}_{2}$ and $2 \mathrm{~mm}-\mathrm{DTT}$. Cell suspensions were either used directly or stored at $-40{ }^{\circ} \mathrm{C}$. It appeared that storage of suspensions under these conditions during a period of up to 3 months did not affect the activity of the enzymes considered here. Extracts were prepared by sonication at $4{ }^{\circ} \mathrm{C}$ with an MSE $150 \mathrm{~W}$ sonicator for $4 \mathrm{~min}$. Unbroken cells and debris were removed by centrifugation at $75000 \mathrm{~g}$. The supernatant which usually contained $6-10 \mathrm{mg}$ protein ml-1 was used as cell-free extract.

Enzyme assays. Spectrophotometric assays were carried out with freshly prepared extracts with a model 100-60 Hitachi spectrophotometer. In all assays, the reaction velocity was linearly proportional to the amount of extract present. Dialysis of extracts against sonication buffer did not result in activity changes of any of the enzymes tested, which indicates the absence of low-molecular-weight effectors in these extracts. The assay mixtures for the individual enzymes are described below.

Acetaldehyde dehydrogenase $\left(\mathrm{NAD}^{+}\right.$or $\left.\mathrm{NADP}^{+}\right)(\mathrm{EC}$ 1.2.1.5 and EC 1.2.1.4): potassium phosphate buffer, pH $8.0,100 \mathrm{mM} ; \mathrm{KCl}, 10 \mathrm{~mm}$; pyrazole, $15 \mathrm{~mm}$; DTT, $0.2 \mathrm{~mm}$; $\mathrm{NAD}^{+}$or $\mathrm{NADP}^{+}, 0.4 \mathrm{~mm}$. The reaction was started with acetaldehyde $(50 \mathrm{mM})$.

Alcohol dehydrogenase (EC 1.1.1.1): potassium phosphate buffer, $\mathrm{pH} 7.5,50 \mathrm{~mm}$; $\mathrm{NAD}^{+}, 0.4 \mathrm{~mm}$. The reaction was started with ethanol (100 $\mathrm{mm})$.

Glucose-6-phosphate dehydrogenase (EC 1.1.1 .49): Tris/ $\mathrm{HCl}$ buffer, $\mathrm{pH} 8.0,50 \mathrm{~mm} ; \mathrm{MgCl}_{2}, 5 \mathrm{~mm}$; NADP ${ }^{+}$, $0.4 \mathrm{~mm}$. The reaction was started with glucose 6-phosphate $(5 \mathrm{~mm})$.

6-Phosphogluconate dehydrogenase (EC 1.1 . 1 .44): glycylglycine buffer, $\mathrm{pH} 8.0,50 \mathrm{~mm}$; NADP $+0 \cdot 4 \mathrm{~mm}$. The reaction was started with 6-phosphogluconate $(2 \mathrm{mM})$.

Isocitrate dehydrogenase $\left(\mathrm{NADP}^{+}\right)(\mathrm{EC} 1.1 .1 .42)$ : potassium phosphate buffer, $\mathrm{pH} 7 \cdot 0,100 \mathrm{mM} ; \mathrm{MgCl}_{2}$, $5 \mathrm{mM}$; $\mathrm{NADP}^{+}, 0.4 \mathrm{mM}$. The reaction was started with trisodium isocitrate $(1 \mathrm{~mm})$.

Isocitrate dehydrogenase $\left(\mathrm{NAD}^{+}\right)(\mathrm{EC} 1.1 .1 .41)$ : potassium phosphate buffer, $\mathrm{pH} 7 \cdot 0,100 \mathrm{mM} ; \mathrm{MgCl}_{2}$, $2.5 \mathrm{~mm}$; AMP, $0.5 \mathrm{mM}$; NAD ${ }^{+}, 0.4 \mathrm{mM}$. The reaction was started with trisodium isocitrate ( $\left.5 \mathrm{~mm}\right)$. This assay was performed in reaction mixtures which were flushed with nitrogen.

Fructose-1,6-bisphosphatase (EC 3.1.3.11): Tris/HCl buffer, $\mathrm{pH} 8.0,50 \mathrm{~mm}$; EDTA, $1 \mathrm{~mm} ; \mathrm{MgCl}_{2}, 5 \mathrm{~mm}$; glucose-6-phosphate dehydrogenase, 1 unit; glucose-6-phosphate isomerase, 1 unit; NADP+, $0 \cdot 4$ mM. The reaction was started with fructose-1,6-bisphosphate (2 mM).

Fructose-1,6-bisphosphatase aldolase (EC 4.1.2. 13): Tris/ $\mathrm{HCl}$ buffer, $\mathrm{pH} 7 \cdot 5,50 \mathrm{mM} ; \mathrm{KCl}, 10 \mathrm{~mm}$; glycerol-3phosphate dehydrogenase, $0 \cdot 8$ unit; triose phosphate isomerase, 10 units; NADH, $0 \cdot 15 \mathrm{~mm}$. The reaction was started with fructose-1,6-bisphosphate (2 mM).

Phosphof ructokinase (EC 2.7.1.11): Tris/ $\mathrm{HCl}$ buffer, $\mathrm{pH} 7 \cdot 5,50 \mathrm{~mm} ; \mathrm{DTT}, 0 \cdot 2 \mathrm{~mm} ; \mathrm{MgCl}_{2}, 5 \mathrm{~mm}$; fructose1,6-bisphosphate aldolase 0.9 unit; glycerol-3-phosphate dehydrogenase, 0.8 unit ; triose phosphate isomerase, 10 units; NADH, $0 \cdot 15 \mathrm{~mm}$; fructose 6-phosphate, $2 \mathrm{~mm}$. The reaction was started with ATP $(0 \cdot 15 \mathrm{~mm})$.

Transaldolase (EC 2.2.1.2): triethanolamine buffer, pH 7.8, $100 \mathrm{~mm}$; EDTA, $20 \mathrm{~mm}$; glycerol-3-phosphate dehydrogenase, 0.8 unit ; triose phosphate isomerase, 10 units; NADH, $0.15 \mathrm{~mm}$; fructose 6-phosphate, $2 \mathrm{~mm}$. The reaction was started with erythrose 4 -phosphate $(0.5 \mathrm{~mm})$. 


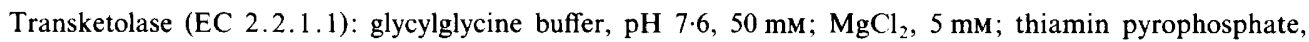
$0.2 \mathrm{~mm}$; glycerol-3-phosphate dehydrogenase, 0.8 unit; triose phosphate isomerase, 10 units; NADH, $0.15 \mathrm{~mm}$; xylulose 5 -phosphate, $0 \cdot 4 \mathrm{~mm}$. The reaction was started with ribose 5 -phosphate $(2 \mathrm{~mm})$.

Xylose reductase (EC 1.1.1.21): potassium phosphate buffer, $\mathrm{pH} 6.0,50 \mathrm{~mm}$; DTT, $0.2 \mathrm{~mm}$; NADPH, $0.15 \mathrm{~mm}$. The reaction was started with xylose (100 mM).

Xylitol dehydrogenase (EC 1.1.1.14): Tris/ $\mathrm{HCl}$ buffer, $\mathrm{pH} 8 \cdot 0,100 \mathrm{mM} ; \mathrm{MgCl}_{2}, 5 \mathrm{~mm} ; \mathrm{NAD}^{+}, 0 \cdot 4 \mathrm{mM}$. The reaction was started with xylitol (100 mM).

Nitrate reductase (EC 1.6.6.3): potassium phosphate buffer, $\mathrm{pH} 7 \cdot 0,50 \mathrm{~mm}$; NADPH, $0 \cdot 15 \mathrm{~mm}$. The reaction was started with $\mathrm{KNO}_{3}(10 \mathrm{mM})$.

Nitrite reductase (EC 1.6.6.4): potassium phosphate buffer, $\mathrm{pH} 7.0,50 \mathrm{~mm} ; \mathrm{MgSO}_{4}, 10 \mathrm{~mm}$; NADPH, $0.15 \mathrm{~mm}$. The reaction was started with $\mathrm{NaNO}_{2}(2.5 \mathrm{~mm})$.

Glutamate dehydrogenase $\left(\mathrm{NAD}^{+}\right)(\mathrm{EC} 1.4 .1 .2)$ : potassium phosphate buffer, $\mathrm{pH} 7 \cdot 0,50 \mathrm{mM}$; DTT, $0 \cdot 2 \mathrm{mM}$; $\mathrm{NADH}, 0.15 \mathrm{~mm} ; 2$-oxoglutaric acid, $5 \mathrm{~mm}$. The reaction was started with $\left(\mathrm{NH}_{4}\right)_{2} \mathrm{SO}_{4}(35 \mathrm{~mm})$.

Glutamate dehydrogenase $\left(\mathrm{NADP}^{+}\right)(\mathrm{EC}$ 1.4.1.4): potassium phosphate buffer, $\mathrm{pH} 7 \cdot 5,50 \mathrm{~mm}$; DTT, $0.2 \mathrm{mM}$; NADPH, $0 \cdot 15 \mathrm{~mm} ; 2$-oxoglutaric acid, $5 \mathrm{~mm}$. The reaction was started with $\left(\mathrm{NH}_{4}\right)_{2} \mathrm{SO}_{4}(35 \mathrm{~mm})$.

Malic enzyme (EC 1.1.1.38): triethanolamine buffer, $\mathrm{pH} 7 \cdot 5,50 \mathrm{~mm} ; \mathrm{MnCl}_{2}, 1 \mathrm{~mm} ; \mathrm{NADP}^{+}, 0 \cdot 4 \mathrm{~mm}$. The reaction was started with malate $(2 \mathrm{~mm})$.

Formate dehydrogenase (EC 1.2.1.2): potassium phosphate buffer, pH 7.0, $50 \mathrm{~mm}$; $\mathrm{NAD}^{+}, 0 \cdot 4 \mathrm{~mm}$. The reaction was started with formate $(50 \mathrm{~mm})$.

Transhydrogenase (EC 1.6.1.1), assayed according to $\mathrm{Krul}$ (1975): Tris/HCl, $\mathrm{pH} \mathrm{7.6,50} \mathrm{mM;} \mathrm{thio-} \mathrm{NAD}^{+}$, $0.15 \mathrm{~mm}$; NADPH, $0.15 \mathrm{~mm}$. The reaction was started with cell-free extract. A blank without thio- $\mathrm{NAD}^{+}$was run in parallel. Oxidation of NADPH and reduction of thio-NAD ${ }^{+}$were measured at 340 or $398 \mathrm{~nm}$, respectively. Specific activities of the various enzymes are expressed as nmol min $\mathrm{m}^{-1}(\mathrm{mg} \text { protein })^{-1}$ and are the average of two or three determinations in extracts of different cultures.

Protein determination. Protein concentrations in cell-free extracts were determined by the Lowry method with bovine serum albumin as a standard.

Biochemicals. Erythrose 4-phosphate, xylulose 5-phosphate, DTT and thio-NAD ${ }^{+}$were from Sigma. Other biochemicals and enzymes were from Boehringer Mannheim.

\section{RESULTS}

The activities of enzymes catalysing NADPH-producing or NADPH-consuming reactions in Candida utilis, grown in chemostat cultures on glucose, xylose or gluconate with various nitrogen sources are shown in Table 1. NADP+-linked malic enzyme and transhydrogenase (energydependent or energy-independent) were not detectable in extracts of cells from these cultures when tested by standard assay procedures in various buffers, with or without chelating agents, SH-protecting agents, mono- or divalent cations, and at various substrate concentrations. In addition, NADP ${ }^{+}$-linked acetaldehyde dehydrogenase was absent during growth on glucose, xylose or gluconate, thus ruling out the theoretical possibility of NADPH generation by this enzyme via a decarboxylation of pyruvate, produced in glycolysis. Only during growth with methylamine as a nitrogen source were low levels of $\mathrm{NADP}^{+}$-dependent acetaldehyde dehydrogenase detected, probably as a result of induction by formaldehyde which is produced from methylamine by amine oxidase (Zwart et al., 1980).

The data shown in Table 1 indicate that both the HMP pathway and the NADP+-dependent isocitrate dehydrogenase reaction are potential sources of NADPH during growth of the organism on glucose, xylose or gluconate. During growth on these carbon sources with nitrate, the NADPH requirement for biosynthesis is increased severalfold as a result of the NADPHdependent reduction of nitrate to ammonia (Bruinenberg et al., 1983). Both nitrate and nitrite reductase were only present during growth with nitrate and were strictly dependent on NADPH. Growth with nitrate resulted in an increase of the enzymes of the HMP pathway as compared to growth with ammonia, which is consistent with the important role of this route in NADPH formation in yeasts. The levels of NADP+-dependent isocitrate dehydrogenase only slightly increased during growth with nitrate.

A large difference in NADP ${ }^{+}$-linked glutamate dehydrogenase levels between ammoniagrown and nitrate-grown cells was observed. Increased levels of this enzyme are probably required as a result of a low intracellular ammonium concentration during growth with nitrate, a situation which may be comparable to nitrogen-limited growth (Burn et al., 1974). 


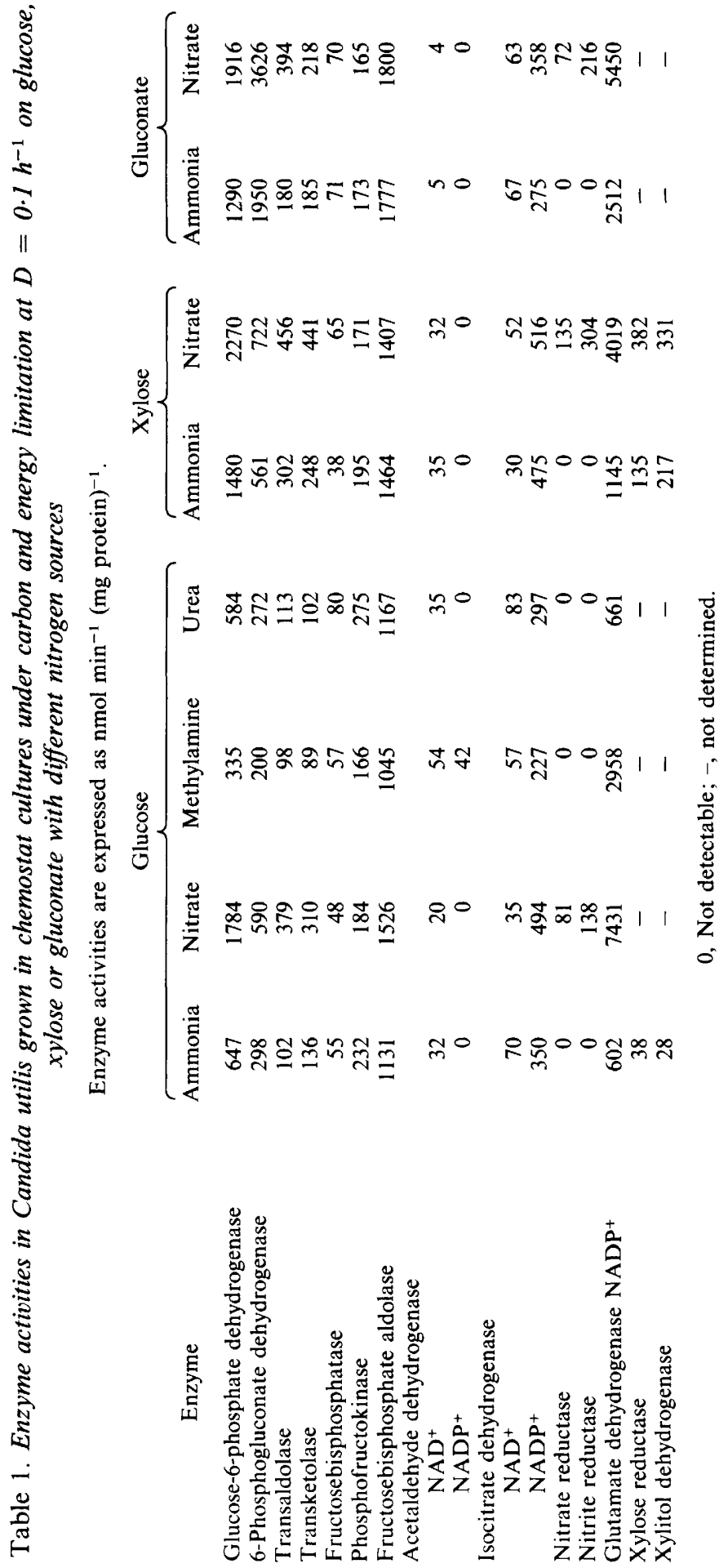


Table 2. Enzyme activities in Candida utilis grown in chemostat cultures under carbon and energy limitation at $D=0.1 \mathrm{~h}^{-1}$ on acetate or ethanol with ammonia or nitrate as nitrogen source

Enzyme activities are expressed as $n m_{0 l} \min ^{-1}(\mathrm{mg} \text { protein })^{-1}$.

Enzyme

Glucose-6-phosphate dehydrogenase

6-Phosphogluconate dehydrogenase

Transoldolase

Transketolase

Fructosebisphosphatase

Phosphof ructokinase

Fructosebisphosphate aldolase

Acetaldehyde dehydrogenase

$$
\mathrm{NAD}^{+}
$$

$\mathrm{NADP}^{+}$

Isocitrate dehydrogenase

$\mathrm{NAD}^{+}$

$\mathrm{NADP}^{+}$

Nitrate reductase

Nitrite reductase

Glutamate dehydrogenase NADP+

\begin{tabular}{cc}
\multicolumn{2}{c}{ Acetate } \\
Ammonia & Nitrate \\
488 & 1218 \\
239 & 489 \\
78 & 245 \\
121 & 163 \\
143 & 140 \\
151 & 179 \\
1057 & 1350 \\
& \\
47 & 47 \\
8 & 17 \\
& \\
40 & 70 \\
530 & 870 \\
0 & 75 \\
0 & 312 \\
410 & 4004
\end{tabular}

$\begin{array}{cc}\overbrace{\text { Ammonia }} & \text { Nitrate } \\ 403 & 1108 \\ 195 & 275 \\ 83 & 227 \\ 94 & 154 \\ 117 & 135 \\ 134 & 147 \\ 815 & 1135\end{array}$

0 , Not detectable.

Table 3. Enzyme activities in Candida utilis grown in chemostat cultures under carbon and energy limitation at $D=0.1 h^{-1}$ on a mixture of glucose $\left(5 \mathrm{gl}^{-1}\right)$ and formate $\left(5 \mathrm{gl}^{-1}\right)$ with ammonia or nitrate as nitrogen source

Enzyme activities are expressed as $\mathrm{nmol} \mathrm{min}^{-1}(\mathrm{mg} \text { protein) })^{-1}$.

\section{Enzyme}

Glucose-6-phosphate dehydrogenase

6-Phosphogluconate dehydrogenase

Transaldolase

Transketolase

Fructosebisphosphatase

Phosphof ructokinase

Fructosebisphosphate aldolase

Acetaldehyde dehydrogenase

$\mathrm{NAD}^{+}$

$\mathrm{NADP}^{+}$

Isocitrate dehydrogenase

$\mathrm{NAD}^{+}$

$\mathrm{NADP}^{+}$

Nitrate reductase

Nitrite reductase

Glutamate dehydrogenase NADP+

Formate dehydrogenase NAD ${ }^{+}$

$\begin{array}{cr}\text { Ammonia } & \text { Nitrate } \\ 630 & 1548 \\ 271 & 544 \\ 150 & 374 \\ 136 & 252 \\ 56 & 81 \\ 238 & 255 \\ 1303 & 1631 \\ & \\ 26 & 33 \\ 0 & 0 \\ & \\ 78 & 70 \\ 265 & 334 \\ 0 & 110 \\ 0 & 189 \\ 543 & 4114 \\ 176 & 207\end{array}$

0 , Not detectable.

Methylamine-grown cells showed a similar response. However, in contrast to growth with nitrate, the enzymes of the HMP pathway remained low during growth with this nitrogen source, the utilization of which does not require an extra input of NADPH. Also during growth with urea the levels of the HMP pathway enzymes were not increased.

Cells of Candida utilis grown on ethanol or acetate showed roughly the same enzyme profiles (Table 2). Also in this case growth with nitrate resulted in elevated levels of the HMP pathway enzymes, whereas the NADP ${ }^{+}$-dependent isocitrate dehydrogenase was only slightly increased in activity. However, in ethanol-grown cells the activity of this enzyme was much lower than in 
cells grown on the other carbon sources (Tables 1 and 2). During growth on ethanol an NADP+_ dependent acetaldehyde dehydrogenase may also contribute to NADPH synthesis, since the activity of this enzyme was strongly increased as compared to cells grown on other carbon sources.

The results presented above strongly suggest that NADPH production in Candida utilis occurs exclusively in intermediary pathways of carbon metabolism and that direct synthesis of NADPH from NADH does not occur. This view is further supported by the enzyme profiles of cells grown on mixtures of glucose and formate. Formate is utilized in chemostat cultures by Candida utilis and other yeasts as an additional source of energy in the presence of a suitable carbon and energy source with a concomitant increase in cell yield (P. M. Bruinenberg, unpublished results). Utilization of formate proceeds via an $\mathrm{NAD}^{+}$-dependent formate dehydrogenase (Table 3 ) which is absent in cells grown on glucose alone (data not shown). Thus, consumption of formate in the presence of glucose results in an enhanced reduction of $\mathrm{NAD}^{+}$. If a transhydrogenase contributed significantly to the production of NADPH, it might be anticipated that utilization of formate would allow a decrease in the activities of other NADPHgenerating enzymes. The results summarized in Table 3, however, show that utilization of formate in the presence of glucose does not change the enzyme profile. The levels of the HMP pathway enzymes and of NADP+-dependent isocitrate dehydrogenase in cells grown on glucose + formate are comparable to those growing on glucose alone (compare Tables 1 and 3).

\section{DISCUSSION}

In Candida utilis NADPH may be generated via the oxidative steps of the HMP pathway and by NADP+-linked oxidation of isocitrate. The enzymes catalysing these reactions were present under all growth conditions tested (Tables 1 and 2). During growth on ethanol, additional NADPH formation may occur in the oxidation of acetaldehyde to acetate via an inducible $\mathrm{NADP}^{+}$-linked aldehyde dehydrogenase (Table 2). Transhydrogenase activity could not be detected. The enzyme levels of NADPH-producing pathways in the presence of formate as an additional source of NADH (Table 3) indirectly confirm the absence of this enzyme or another transhydrogenating system, such as a mannitol cycle (Hult et al., 1980). A similar conclusion, based on radiorespirometric studies, was drawn by Lagunas \& Gancedo (1973) for glucosegrown Saccharomyces cerevisiae. To our knowledge, neither direct nor indirect evidence for the operation of a transhydrogenase in yeasts has been obtained so far. One of the consequences of the lack of transhydrogenase activity might by the inability of yeasts to ferment xylose anaerobically via xylitol (Bruinenberg et al., 1982).

Under all growth conditions tested fructose-1,6-bisphosphatase activity was present. Consequently, even during growth on $\mathrm{C}_{6}$ compounds, glucose 6-phosphate may be completely oxidized to $\mathrm{CO}_{2}$ in the HMP pathway via glucose-6-phosphate dehydrogenase, 6-phosphogluconate dehydrogenase, transaldolase, transketolase and fructose-1,6-bisphosphatase (see Bruinenberg et al., 1983). In Saccharomyces cerevisiae fructose-1,6-bisphosphatase activity is strongly repressed by glucose, even in carbon-limited chemostat cultures $(J$. P. van Dijken and R. Jonker, unpublished). In Rhodotorula yeasts, on the other hand, this enzyme is synthesized even in the presence of excess glucose (Gancedo \& Gancedo, 1971). It is tempting to speculate that the presence of this enzyme in glucose-grown yeasts may be indicative of a highly active HMP pathway, since Candida utilis and Rhodotorula yeasts may catabolize $50 \%$ or more of the glucose via this route, whereas in Saccharomyces cerevisiae the pathway is less active (Suomalainen \& Oura, 1971). At present it is not known whether in Candida utilis during growth on glucose fructose-1,6-bisphosphatase is indeed active in vivo. Both this enzyme and phosphofructokinase are probably synthesized constitutively in this organism (Tables 1-3), thereby permitting futile cycling.

The activities of the HMP pathway enzymes in cells grown on glucose or xylose follow the theoretical prediction, made on the basis of the NADPH requirement for biomass formation under these growth conditions. Thus, all the enzymes of the HMP pathway, except fructose-1,6bisphosphatase, are increased in cells grown with nitrate as compared to cells grown with 
ammonia. During growth on xylose + ammonia the activities are higher than during growth on glucose + ammonia, which is in accordance with the high NADPH requirement for biomass synthesis from xylose (Bruinenberg et al., 1983). This high NADPH requirement results from the necessary initial reduction of xylose to xylitol via an inducible NADPH-linked enzyme (Table 1). An even higher level of the HMP pathway enzymes was observed during growth on xylose + nitrate, which requires a higher expenditure of NADPH, as a result of the NADPH-dependent reduction of nitrate to ammonia via the nitrate and nitrite reductases. In contrast to Candida utilis CBS 621, the nitrate reductase of Candida utilis NCYC 426 is NADH-dependent, whereas the nitrite reductase in this strain is also NADPH-linked (Burn et al., 1974; P. M. Bruinenberg, unpublished).

Also acetate-grown cells have increased levels of HMP pathway enzymes during growth with nitrate, as compared to growth with ammonia. This may indicate that even during growth on acetate this route is functioning for the production of NADPH, as predicted by Bruinenberg et al. (1983) on theoretical grounds.

The metabolism of gluconate in Candida utilis proceeds via NADP+-linked 6-phosphogluconate dehydrogenase. This enzyme was present at high levels during growth on gluconate and ammonia. Surprisingly, however, glucose-6-phosphate dehydrogenase also was present at levels comparable to those during growth on xylose + ammonia. Since NADPH requirements for growth on xylose and gluconate are very different, it is questionable whether levels of glucose-6phosphate dehydrogenase (and probably of the other HMP pathway enzymes as well) can be regarded as a reflection of the NADPH demand of the cell. The same holds for growth on ethanol, which may have a much lower NADPH requirement than growth on acetate. This difference depends on the relative contribution of an NADP ${ }^{+}$-linked acetaldehyde dehydrogenase in the conversion of ethanol to acetate. Nevertheless, with acetate and ethanol comparable levels of HMP pathway enzymes were observed. It is evident therefore that further radiorespirometric studies have to be performed to determine to what extent the observed differences in enzyme levels reflect an operational activity in vivo.

The authors are indebted to Professor Dr J. G. Kuenen for valuable discussions.

\section{REFERENCES}

Bruinenberg, P. M., van Dijken, J. P. \& SchefFers, W. A. (1982). Bildung und Verbrauch von NADPH während des Wachstums von Candida utilis auf Xylose. Abstracts 5. Symposium Technische Mikrobiologie, Institut für Gärungsgewerbe und Biotechnologie, Berlin.

Bruinenberg, P. M., van Dijken, J. P. \& Scheffers, W. A. (1983). A theoretical analysis of NADPH production and consumption in yeasts. Journal of General Microbiology 129, 953-964.

Burn, V. J., Turner, P. R. \& Brown, C. M. (1974). Aspects of inorganic nitrogen assimilation in yeasts. Antonie van Leeuwenhoek 40, 93-102.

GANCEDO, J. M. \& GANCEDo, C. (1971). Fructose-1,6diphosphatase, phosphof ructokinase and glucose-6phosphate dehydrogenase from fermenting and nonfermenting yeasts. Archir für Mikrobiologie 76, 132 138.

Gancedo, J. M. \& Lagunas, R. (1973). Contribution of the pentose-phosphate pathway to glucose metabolism in Saccharomyces cererisiae: a critical analysis on the use of labelled glucose. Plant Science Letters 1 , $193-200$.

Hankinson, O. \& Cove, P. J. (1974). Regulation of the pentose phosphate pathway in the fungus Aspergillus nidulans. Journal of Biological Chemistry 249, 2344 2353.

Hirai, M., Shiotani, T., Tanaka, A. \& Fukui, S. (1976). Effects of carbon and nitrogen sources on the levels of several NADP- and NAD-linked dehydrogenase activities of hydrocarbon-utilizable Candida yeasts. Agricultural and Biological Chemistry 40, 1819 1827.

Hult, K., Veide, A. \& Gatenbeck, S. (1980). The distribution of the NADPH regenerating mannitol cycle among fungal species, Archices of Microbiology 128, 253255.

KRUL, J. (1975). A study on the $N A D(P)^{+}$transhydrogenase from Azotobacter tinelandii. Ph.D. thesis, Landbouw Hogeschool Wageningen.

Lagunas, R. \& Gancedo, J. M. (1973). Reduced pyridine-nucleotides balance in glucose-growing Saccharomyces cererisiae. European Journal of Biochemistry 37, 9094.

Osmond, C. B. \& AP ReEs, T. (1969). Control of the pentose-phosphate pathway in yeast. Biochimica et biophysica acta 184, 35-42.

Slomalainen, H. \& Olra, E. (1971). Yeast nutrition and solute uptake. In The Yeasts, vol. 2, pp. 3-74. Edited by A. H. Rose \& J. S. Harrison. London \& New York: Academic Press.

ZWart, K., Veenhuis, M., van DiJken, J. P. \& HARDER, W. (1980). Development of amine oxidasecontaining peroxisomes in yeasts during growth on glucose in the presence of methylamine as the sole source of nitrogen. Archices of Microbiology 126, $117-$ 126. 